\title{
SYSTEMIC LIMITATIONS OF THE COMPETITIVENESS OF SERBIA'S ECONOMY
}

\author{
Ljiljana Maksimovic* \\ Faculty of Economics, University of Kragujevac, Kragujevac, Serbia
}

\begin{abstract}
The paper analyzes the ways for measuring competitiveness as well as the Global Competitiveness Index which, pursuant to the methodology of the World Economic Forum, ranks countries' competitiveness within global frameworks. The analysis begins with a hypothesis that the macroeconomic performances of national economies are positively correlated with their global competitiveness index, which has been shown on the examples of Serbia, Croatia, Slovenia and Slovakia. The other hypothesis is that the bad macroeconomic performances of the Serbian economy and its bad ranking according to the Global Competitiveness Index are the result of the systemic limitations in the Serbian economy. The analysis presented in the paper shows that systemic limitations such as the concept of transition (privatization) and its realization, the concept of macroeconomic stabilization, the concept of institutional reforms and the concept of restructuring economy are the main originators of the non-competitiveness of Serbia's economy.
\end{abstract}

Keywords: competitiveness, The Global Competitiveness Index, systemic limitations

JEL Classification: E02, D02, F43, O11, 012

\section{INTRODUCTION}

The subject of the analysis is the competitiveness of Serbia's economy, which is being compared to the competitiveness of Slovenia, Croatia and Slovakia. The aim of the paper is to show that the systemic limitations in Serbia's economy were more emphasized than those of the aforementioned countries in transition, which is reflected in the balance of trade and the global competitiveness index of the observed countries. The paper starts from the following hypotheses: the first

\footnotetext{
* Correspondence to: Lj. Maksimovic, Faculty of Economics, University of Kragujevac, Dj. Pucara 3, 34000 Kragujevac, Serbia; e-mail: maksimoviclj@kg.ac.rs
}

Review paper

UDC: 338:339.137.2(497.11)

doi: 10.5937/ekonhor1202099M 
competitiveness index and the GDP $\mathrm{p} / \mathrm{c}$ of the analyzed countries.

\section{THE CONCEPT OF NATIONAL COMPETITIVENESS}

Economists have different ways of understanding and defining national competitiveness, therefore the concepts of national, international and global competitiveness overlap in many aspects. In addition to various formal differences in defining national, international and global competition, most definitions contain many common elements. Thus, all the definitions of competitiveness highlight a country's ability to achieve the high sustainable economic growth rates of the GDP $\mathrm{p} / \mathrm{s}$ and its ability to produce goods and services that meet the world market test. In accordance with a variety of competitiveness concepts, different approaches for measuring competitiveness have been developed. McFetridge (1995) concluded that, generally, two options in measuring competitiveness can be distinguished. The first is based on determining income per capita or productivity growth, and the other on determining the performance of international trade.

The contemporary concept of the competitiveness of an economy means that companies struggle for markets and resources and use business strategies to improve their performances and profitability at the national and international level. It connects the micro- and macroeconomic factors of competitiveness (Nurbel, 2007) or price competitiveness (which is a microeconomic concept) with the balance of trade (whichisamacroeconomic concept). Themicroeconomic concept of price competitiveness is based on the costs and the business strategy of a firm and affects the balance of trade through export and import prices. On the other hand, the macroeconomic factors such as exchange rates (which a firm cannot have an influence on), affect a firm's price competitiveness. The microeconomic decisions of a firm and macroeconomic factors affect the price competitiveness of export and import, and price competitiveness is the force driving trade flows and affects the balance of trade.
Price competitiveness is not the only determinant of the balance of trade. The balance of trade reflects the collective actions of individual consumers, firms and the government, and is the difference between domestic aggregate production and aggregate consumption. When a country spends more than it produces, it will have a deficit even if workers (in terms of pay) and producers (in terms of product prices) are competitive in the world market.

Prices are the measure of competitiveness at a given moment. In the long-term, competitiveness is based on the quality of the resources that firms utilize in the production of goods and services, as well as on the decisions of households, firms and the government on how to spend and save. In addition, there are many factors influencing the long-term capacity of a country to produce and compete on the world market: the efficiency with which financial markets transform savings into investments, the ability and speed of accepting technological innovations, the ability of workers to acquire the skills demanded by the labor market, the quality of the business decisions made by the management and the government's policy-related decisions and other factors (Dani, 2007).

Today, attention is focused on the importance of the competitive advantages of nations and their impact on economic growth and living standards (Porter, 2001). The basic idea is that if a country effectively identifies the true source of its competitiveness, it will face fewer problems during its economic development. In this context, competitiveness is linked to productivity. Productivity growth is the key factor of the growth of income per capita; the key factor of productivity growth is innovation; the key factor of innovation is the functioning of the diamond of the national advantage (cluster) as an innovative system. According to Porter (1990), the countries with strong clusters will have higher rates of productivity growth and an unquestionable advantage compared to the countries with weak clusters. In this context, it is important to understand the determinants of productivity and the rate of productivity growth in specific industries and the industry's segments (Porter, 2008). 
According to Porter (1990) the international competitiveness is determined by the following phenomena: 1) the macroeconomic phenomena such as exchange rates, interest rates, a budget deficit, 2) the cheap and abundant labor force, 3 ) the availability of natural resources, 4) various management practices, 5) low unit labor costs, 6) a positive balance of trade, and 7) high and constantly increasing productivity.

Paul Krugman (1994) criticized the concept of national competitiveness, pointing out that domestic factors are the ones that dominantly influence the level of the GDP $\mathrm{p} / \mathrm{s}$ and welfare, not the national competitiveness confirmed in the global market. He emphasizes that, in defining national competitiveness, the importance of the structural factors (productivity, innovation, and skills) is highlighted and the essence of the competitive advantage is ignored, and those are comparative advantages. When economies trade, they do not compete in a confrontational way (as firms do); instead, they operate so that each side has some benefits (a plus-sum game). Countries specialize in goods that are produced cheaply, i.e., in those whose opportunity costs are lower (Krugman \& Obstfeld, 2003).

Although analysts have pointed out the shortcomings and deficiencies in its drafting (Smith, 2010), today, the widely accepted indicator of the global competitiveness of countries is the Global Competitiveness Index (GCI), established according to the methodology of the World Economic Forum (WEF). Researchers of the WEF, with the help of the GCI concept, conducted a synthesis of the micro- and macroeconomic indicators of competitiveness, taking into account and harmonizing the recommendations of the theory of the growth and development of contemporary institutional economics and applied business economics. In this way, they theoretically and practically linked the strategic aspects of business competitiveness at the level of an individual company with the total environment at the level of the sectors, industries and the whole economy (Maksimović, 2010a). The analysis showed (Schuller \& Lidbom, 2009) that countries highly ranked according to the GCI are highly ranked according to income per capita and the standard of living. Pearson's coefficient of correlation between the rank of the GCI and the GDP per capita is very high and positive.
The GCI is a composite index formed as the weighted average value of the twelve pillars of competitiveness (Institutions, Infrastructure, Macroeconomic stability, Health and primary education, Higher education and training, Goods market efficiency, Labor market efficiency, Financial market sophistication, Technological readiness, Market size, Business sophistication, and Innovation). The pillars include microeconomic and macroeconomic factors which, together with institutions, determine the competitiveness of a national economy in global terms. Each of these pillars is a composite index formed as the weighted average of sub-indicators. Composite indicators are obtained by aggregating a number of individual indicators measuring the specific dimensions of the observed multi-dimensional phenomenon. The methodology for the construction of composite indexes relies on a consistent theoretical framework, a choice of individual indicators, the use of the appropriate type of a multivariate analysis and determining the system of weights and aggregation procedures. The values of sub-indicators are obtained either from statistical reports or based on standardized questionnaires, filled out by the "top" management of a company's representative sample every year. The value of sub-indicators, for which there are no internationally comparable databases, is determined only on the basis of the survey, ranking from 1 to 7 (the business conditions, the market climate, the freedom of the press, the efficiency of the legal framework, the political situation, the financial market sophistication, the effectiveness of the anti-monopoly policy).

For calculating the competitiveness, sub-indicators such as inflation, the budget deficit, thetax level, the number of telephone lines, and the number of procedures to start a business, the internationally comparable databases of the United Nations, the World Bank, the IMF, and the World Trade Organization are used. Within the GCI, the data from the survey (the primary data or soft data) have an about-70\% share, while the secondary ones (the hard data) have a share of about $30 \%$.

The fact that some categories, those considered to be important for the competitive profile of a country, can only be assessed through a survey, includes 
a possibility that the rating of sub-indicators may be over- or underestimated. The unrealistic rating of sub-indicators is transferred from the pillars of competitiveness to the final value of the Global Competitiveness Index and a country's ranking.

\section{THE COMPETITIVE POSITION OF SERBIA, CROATIA, SLOVENIA AND SLOVAKIA}

Serbia's position in the WEF competitiveness report is very unfavorable. In the WEF report 2011, Serbia was ranked $95^{\text {th }}$ on the list of 142 countries, while Croatia was ranked $76^{\text {th }}$, Slovenia $57^{\text {th }}$ and Slovakia $69^{\text {th }}$.

Table 1 Rank and index value for Serbia, Croatia, Slovenia and Slovakia in 2011

\begin{tabular}{|c|c|c|c|c|c|c|}
\hline Country & 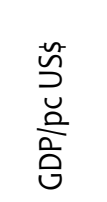 & 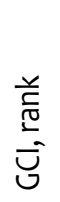 & 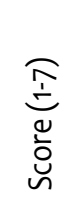 & 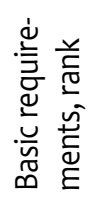 & 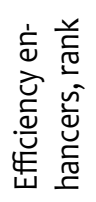 & 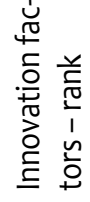 \\
\hline Serbia & 5233 & 95 & 3,9 & 88 & 90 & 118 \\
\hline Croatia & 13720 & 76 & 4,1 & 52 & 72 & 82 \\
\hline Slovenia & 23706 & 57 & 4,3 & 39 & 51 & 45 \\
\hline Slovakia & 16104 & 69 & 4,2 & 60 & 44 & 71 \\
\hline
\end{tabular}

Source: The Global Competitiveness Report 2011-2012

According to the GDP per capita (US\$ 5233) and the methodology of the WEF, Serbia is at the middle level of development, i.e. in the second phase of development, in which the key drivers of competitiveness are the pillars of the Efficiency enhancers group. The low values of the sub-indicators from this group show the real shortcomings of Serbia's competitiveness and consequently its very bad ranking (Table 2).

While the intensity of the local competition in Serbia is of Rank 136, in Slovenia it is 51, in Croatia 115, and in Slovakia 37. According to the firm-level technology absorption, Serbia is $136^{\text {th }}$, Slovenia 84 th, Croatia $80^{\text {th }}$, and Slovakia $58^{\text {th }}$. Serbia is ranked as $139^{\text {th }}$ when it comes to brain drain, while Slovenia is $58^{\text {th }}$, Croatia $-128^{\text {th }}$ and Slovakia $-111^{\text {th }}$. According to the extent of the market dominance, Serbia is ranked as 139th, Slovenia $-63^{\text {th }}$, Croatia $-119^{\text {th }}$, and Slovakia $-50^{\text {th }}$.

Table 2 The weakest sub-indicators from the Efficiency enhancers group in Serbia (2011)

\begin{tabular}{lcc}
\hline Efficiency enhancers & Value & Rank \\
\hline Extent of staff training & 2,9 & 132 \\
Intensity of local competition & 3,6 & 136 \\
Extent of market dominance & 2,5 & 139 \\
Effectivness of the anti-monopoly & 2,8 & 137 \\
policy & 2,2 & 136 \\
Buyer sophistication & 3,3 & 133 \\
Reliance on professional manage- & 1,8 & 139 \\
ment & 3,7 & 136 \\
Brain drain & & 136 \\
Firm-level technology absorption & 3,3 & \\
Cooperation in labor-employer & & \\
relations &
\end{tabular}

Source: The Global Competitiveness Report 2011-2012

Table 3 The share of "soft" and "hard" sub-indicators in the structure of GCI (absolutely and in \%)

\begin{tabular}{lccc}
\hline & \multicolumn{3}{c}{ Number of indicators and \% of } \\
& share \\
\cline { 2 - 4 } & Total & Hard & Soft \\
\cline { 2 - 4 } Basic requirements & 46 & $16(34,8 \%)$ & $30(65,2 \%)$ \\
Efficiency enhancers & 52 & $18(34,6 \%)$ & $34(65,4 \%)$ \\
Innovation and so- & 18 & $1(5,6 \%)$ & $17(/ 94,4 \%)$ \\
phistication factors & & &
\end{tabular}

Source: The Global Competitiveness Report 2011-2012

In the structure of the Efficiency enhancers, the predominant ones are the "soft" indicators (65\%), whose value is determined through the questionnaires. Since this is a subjective rating in the process of an 
international comparison, the under- or overestimation of the sub-indicators and the impact on the objectivity of the position a country takes are possible.

Pearson's correlation index of the (GCI) and the GDP $\mathrm{p} / \mathrm{c}$ rank for the observed countries is very high and amounts to 0.986 , which is indicative of the fact that there is a very strong positive correlation between the productivity and competitiveness rank. To a certain extent, a small sample of only four countries affects the value of Pearson's coefficient.

Comparing the "hard" indicators (the government deficit), the national savings rate in the GDP (\%), the inflation, and the government debt in the GDP (\%), we can observe that Serbia is ranked worse than Slovenia, Croatia and Slovakia (Table 4) for all the indicators, except for the budget deficit.

In relation to the observed countries in 2011, Serbia had the highest inflation (6.2\%), the smallest savings rate in the GDP $(14.8 \%)$ and the largest rate of the government debt in the GDP (44\%).

The macroeconomic indicators for the observed countries (Tables from 5.1 to 5.6), presented in the report of the European Bank for Reconstruction and Development for 2011, show that Serbia had the highest inflation, with the largest deficit of the current account balance $(9,6 \%$ relative to the GDP), with a low rate of economic growth $(1,6 \%)$ and a high budget deficit $(4,8 \%$ relative to the GDP).
Table 5.1 The growth rates of Gross Domestic Product (GDP) in \% (GDP growth)

\begin{tabular}{lcccc}
\hline Country & 2007. & 2008. & 2009. & $2010 .^{*}$ \\
\hline Serbia & 6,9 & 5,5 & $-3,1$ & 1,6 \\
Croatia & 5,5 & 2,4 & $-5,8$ & $-1,5$ \\
Slovenia & 6,9 & 3,7 & $-8,1$ & 1,1 \\
Slovakia & 10,6 & 6,2 & $-4,7$ & 4,0 \\
\hline
\end{tabular}

* Projection

Source: Tranzition Report 2011

Table 5.2 Inflation during the year

\begin{tabular}{lcccc}
\hline Country & 2007. & 2008. & 2009. & $\begin{array}{c}2010 . \\
\text { projection }\end{array}$ \\
\hline Serbia & 11,0 & 8,6 & 6,6 & 7,7 \\
Croatia & 5,8 & 2,9 & 1,9 & 2,8 \\
Slovenia & 5,6 & 2,1 & 1,8 & 2,1 \\
Slovakia & 3,4 & 4,4 & 0,5 & 1,0 \\
\hline
\end{tabular}

Source: Tranzition Report 2011

Table 5.3 Government balance relative to GDP

\begin{tabular}{lcccc}
\hline Country & 2007. & 2008. & 2009. & 2010. \\
\hline Serbia & $-1,9$ & $-2,6$ & $-4,2$ & $-4,8$ \\
Croatia & $-2,5$ & $-1,4$ & $-3,3$ & $-4,7$ \\
Slovenia & 0,0 & $-1,8$ & $-5,8$ & $-5,7$ \\
Slovakia & $-1,8$ & $-2,1$ & $-7,9$ & $-7,5$ \\
\hline
\end{tabular}

Source: Tranzition Report 2011

Table 4 Hard indicators for Serbia, Croatia, Slovenia and Slovakia (2011)

\begin{tabular}{lcccccccc}
\hline Countries & $\begin{array}{c}\text { Budget deficit } \\
(\% \text { GDP })\end{array}$ & Rank & $\begin{array}{c}\text { National savings } \\
\text { (\%GDP) }\end{array}$ & Rank & Inflation & Rank & $\begin{array}{c}\text { Government } \\
\text { debt (\%GDP) }\end{array}$ & Rank \\
\hline Serbia & -3.5 & 66 & 14.8 & 103 & 6.2 & 106 & 44 & 85 \\
Croatia & -5.3 & 99 & 21.7 & 59 & 1.0 & 1 & 40 & 74 \\
Slovenia & -5.2 & 98 & 22.2 & 56 & 1.8 & 1 & 37.2 & 60 \\
Slovakia & -8.2 & 130 & 20.2 & 68 & 0.7 & 1 & 42.0 & 81 \\
\hline
\end{tabular}


Table 5.4 Current account balance in \% relative to GDP

\begin{tabular}{lcccc}
\hline Country & 2007. & 2008. & 2009. & 2010. \\
\hline Serbia & $-15,7$ & $-17,9$ & $-5,6$ & $-9,6$ \\
Croatia & $-7,6$ & $-9,2$ & $-5,2$ & $-3,8$ \\
Slovenia & $-4,8$ & $-6,1$ & $-1,0$ & $-1,0$ \\
Slovakia & $-4,7$ & $-6,3$ & $-3,2$ & $-1,5$ \\
\hline
\end{tabular}

Source: Tranzition Report 2011

Table 5.5 Net FDI (in million US \$)

\begin{tabular}{lcccc}
\hline Country & 2007. & 2008. & 2009. & $\begin{array}{c}2010 . \\
\text { projection }\end{array}$ \\
\hline Serbia & 2523 & 2717 & 1865 & 1364 \\
Croatia & 4736 & 4653 & 1600 & 390 \\
Slovenia & -273 & 514 & -743 & -200 \\
Slovakia & 2881 & 3156 & -481 & 1500 \\
\hline
\end{tabular}

Source: Tranzition Report 2011

Table 5.6 External debt in \% relative to GDP

\begin{tabular}{lcccc}
\hline Country & 2007. & 2008. & 2009. & $\begin{array}{c}2010 . \\
\text { projection }\end{array}$ \\
\hline Serbia & 64,9 & 65,5 & 73,6 & No data \\
Croatia & 83,4 & 81,9 & 101,9 & No data \\
Slovenia & 100,6 & 105,2 & 113,4 & No data \\
Slovakia & 52,7 & 53,4 & 74,3 & No data \\
\hline
\end{tabular}

Source: Tranzition Report 2011

There is a consensus reached by economists that the movement of the GDP is a good initial indicator of the successfulness of the countries' economic development. The EBRD report shows that, out of these countries, only Serbia did not reach the pre-transition level of the GDP, while the other countries had a dynamic growth. Croatia's GDP in 2010 is slightly above the level of the GDP in 1989, Slovenia's GDP is $160 \%$, the
GDP of Slovakia is $145 \%$ and Serbia's GDP is only $70 \%$ compared to the level in 1989.

Serbia's balance of trade deficit represents low economic competitiveness. Tables 6.1.- 6.4. provide an overview of the trade balance of the analyzed countries.

Import, export and international trade deficits of Serbia, Croatia, Slovenia and Slovakia (2007-2010), Tables 6.1. - 6.4.

\section{Table 6.1}

\begin{tabular}{lcccc}
\hline Serbia & 2007. & 2008. & 2009. & 2010. \\
\hline Import $(a+b)$ & 21337 & 26227 & 18791 & 20884 \\
a) products & 18554 & 22875 & 16047 & 16734 \\
b) services & 2783 & 3352 & 2744 & 4150 \\
Export $(c+d)$ & 11445 & 14275 & 11279 & 14018 \\
c) products & 8825 & 10972 & 8345 & 9795 \\
d) services & 2620 & 3303 & 2934 & 4223 \\
Balance $(a+b)-(c+d)$ & -9892 & -11952 & -7512 & -6868 \\
\hline
\end{tabular}

Source: http://www.trademap.org/countrymap/Product_ SelCountry_TS.aspx

Table 6.2

\begin{tabular}{lcccc}
\hline Croatia & 2007. & 2008. & 2009. & 2010. \\
\hline Import (a+b) & 29741 & 35327 & 25073 & 23519 \\
a) products & 25829 & 30727 & 21205 & 20067 \\
b) services & 3912 & 4600 & 3868 & 3452 \\
Export (c+d) & 24877 & 28951 & 22263 & 22831 \\
c) products & 12360 & 14124 & 10492 & 11811 \\
d) services & 12517 & 14827 & 11771 & 11020 \\
Balance $(a+b)-(c+d)$ & -4864 & -6376 & -2810 & -687 \\
\hline
\end{tabular}

Source: http://www.trademap.org/countrymap/Product_ SelCountry_TS.aspx 
Table 6.3

\begin{tabular}{lcccc}
\hline Slovenia & 2007. & 2008. & 2009. & 2010. \\
\hline Import $(a+b)$ & 33716 & 39183 & 28271 & 30740 \\
a) products & 29476 & 33985 & 23844 & 26360 \\
b) services & 4240 & 5198 & 4427 & 4380 \\
Export $(c+d)$ & 32224 & 36640 & 28269 & 29966 \\
c) products & 26551 & 29253 & 22294 & 24188 \\
d) services & 5673 & 7387 & 5975 & 5778 \\
Balance $(a+b)-(c+d)$ & -1492 & -2543 & -2 & -774 \\
\hline
\end{tabular}

Source: http://www.trademap.org/countrymap/Product_ SelCountry_TS.aspx

Table 6.4

\begin{tabular}{lcccc}
\hline Slovakia & 2007. & 2008. & 2009. & 2010. \\
\hline Import $(a+b)$ & 65698 & 82499 & 64143 & 73562 \\
a) products & 59208 & 72612 & 55160 & 65916 \\
b) services & 6490 & 9887 & 8983 & 7646 \\
Export $(c+d)$ & 65058 & 79332 & 62596 & 71244 \\
c) products & 58036 & 70189 & 55553 & 64687 \\
d) services & 7022 & 9144 & 7043 & 6557 \\
Balance $(a+b)-(c+d)$ & -640 & -3167 & -1547 & -2318 \\
\hline
\end{tabular}

Source: http://www.trademap.org/countrymap/Product_ SelCountry_TS.aspx

One of the indicators of Serbia's low competitiveness is its very low export, either viewed in the absolute values or in relation to the population or as the ratio of the exports and the GDP. Based on the data on the GDP and the population from the WEF report for 2011 (8 million people in Serbia, 4.4 million in Croatia, 2.0 million in Slovenia and 5.4 million in Slovakia) and the export value of the analyzed countries, it is concluded that Serbia only had US $\$ 1752$ export per capita, Croatia US\$ 5183, Slovenia US\$ 14983 and Slovakia US\$ 13193. In the year 2010, the coverage of the import by the export was $67.1 \%$ for Serbia, $97.1 \%$ for Croatia, $97.5 \%$ for Slovenia and $96.8 \%$ for Slovakia.

\section{PROBLEMS IN THE TRANSITION OF SERBIA'S ECONOMY}

Economic experts had predicted, and the twenty-year time period has confirmed their predictions, that transition is a long and destabilizing process. The radical transformation from the socialist system into the capitalist one included the implementation of the synchronized activities (macroeconomic stabilization, corporatization, privatization, institutional reform, the liberalization of prices and trade and the foreign trade regime), which inevitably caused the transitional stagflation (a drop in the economic activity and a high inflation). In countries that had been consistent in implementing the transition program and had implemented it in the short term, the transitional crisis lasted for a short time ( 3 to 5 years) and had less severe economic and social consequences. Even ten years after the transition, a number of successful transition economies have reached the level of the GDP from 1989, while Serbia has not achieved it in 2012, either. Transition in Serbia had been slow and inconsistent, further hampered by the disintegration of the country, the wars in the region, the UN sanctions, the NATO bombing and the deep-rooted systemic corruption (Maksimović, 2010b). The ill-conceived privatization process was realized in a disordered institutional environment characterized by the incomplete and conflicting laws and regulations, the underdeveloped and non-transparent procedures. Privatization is not successful if the results of privatization are considered in the light of the proclaimed goals, which are: the increased economic and production efficiency of companies, providing companies' healthy financing; the introduction of efficient management; ensuring the inflow of foreign capital; making space for entrepreneurship; freeing a company from the impact of the state and politics; the increase in the competition; breaking monopolies and limiting their impact; the liquidation of unprofitable companies.

The effects of the growth of the privatized companies' economic efficiency do not significantly influence the growth level of the economic activity. The expectations of the volume of foreign direct investments (FDI) in the real sector did not come true because foreign capital 
was primarily aimed at banks, insurance, monopolistic companies and excise goods, and less at the tradable goods sector. The net amount of the FDI's in the time period 2001-2011 was about 15 billion Euros, of which $40 \%$ was invested in the privatization of the economy and the financial sector. This amount was not sufficient for the recovery of the economy, especially the industry, because about $35 \%$ of the total inflow of the FDI's was directed towards the sector of untradeable goods and services, and only around 15\% were Greenfield investments (Survey of Republic of Serbia, 2012). The efficiency of the FDI's in the privatization process was low: out of 222 companies which were offered for sale by tender in the time period 2002-2010, 108 were sold and 24 contracts were terminated. In the case of the auction privatization, out of 2453 offered companies, 1645 were sold and nearly one-third of the contracts were terminated (501), (Zec \& Radonjić, 2010). The privatization by tender started from the top companies: these are cement factories, tobacco factories, breweries, pharmaceutical companies, oil companies. By such an offer, the state sought to improve the investment image and attract transnational corporations. The smaller companies purchased primarily for the assets and liquidation were sold through auctions. Under the pressure of the entrepreneurial lobbyists, the state sold the companies in auction privatizations at a low starting price, since it valued them as businesses. The buyers were using cheap bank loans to buy the companies with an intention to liquidate them and obtain the property. Entrepreneurship in transition was manifested in the following way: some people became entrepreneurs because they had a possibility of transferring the wealth into their hands through business transactions during hyper-inflation; others used loans for takeovers, mistakenly believing that they could continue taking loans for capital investments and current assets. It turned out that the new entrepreneurs based the survival of their takeovers on the non-economic and political levers.

\section{MACROECONOMIC STABILIZATION}

The quality of macroeconomic stabilization is measured by price stability, a balanced and stable exchange rate of a national currency, the elimination of a state's budget deficit. The economy's macroeconomic performances indicate that there is a constant inflationary pressure in the country, because aggregate demand exceeds aggregate supply. Due to the delay in the restructuring of the public companies and the monetary expansion, primarily caused by the inflow of the credit capital, the fiscal expansion further strengthens the inflationary pressures. Inflation in Serbia was accompanied by the appreciation of the domestic currency, which resulted in a decline in economic competitiveness and a slower growth. Some economists point out that the range of the restrictive monetary policy in controlling inflation is very limited and the exchange rate appreciates even in the regime of free fluctuation, which is explained by the Balassa-Samuelson effect (Candelon, 2000; Djuričin, 2006; Dedu, 2010). Balassa and Samuelson started from the assumption that economy can be divided into two sectors: the tradable goods sector (goods), goods which are the subject of international trade, and nontradable goods sector (services), goods which are not traded on international markets. Productivity grows faster in the tradable goods sector, resulting in the growth of employees' salaries in the sector. Due to the emulation effect, there is the growth of salaries in the non-tradable goods sector, which can only be covered by an increase in prices (Baldwin \& Wyplosz, 2010). By applying the Balassa-Samuelson effect in the case of Serbia, the following conclusion is made: a relatively higher rate of domestic inflation than the one of foreign inflation does not entirely affect the nominal exchange rate, since the prices of tradable goods (which grow more slowly) are more important for its formation than the prices of non-tradable goods (which grow faster). As the purchasing power parity does not work in the transition economies, their currencies depreciate by less than the inflation rate. The result is the appreciation or the slower growth rate of the domestic currency than the inflation increase is. The real appreciation of the Dinar, thanks to which the prices of the products and services in Serbia expressed in Euros have significantly increased, has resulted in large profits in trading. This encourages investments in trade and discourages investments in production.

Serbia is a highly indebted country, which is portrayed in the correlation between the GDP and the external 
Table 7 Serbia's external debt to debtors (mill. EUR)

\begin{tabular}{lrrrrrr}
\hline & 2006. & 2007. & 2008. & 2009. & 2010. & 2011. \\
\cline { 2 - 7 } External debt balance (A+B) & 14182.0 & 17138.7 & 21088.4 & 22487.3 & 23786.4 & 24125.4 \\
A (1+2) Long-term debt & 13224.1 & 16088.7 & 18954.1 & 20482.5 & 21956.0 & 23477.5 \\
1. Public sector & 6535.3 & 6251.1 & 6503.0 & 7762.3 & 9076.4 & 10773.3 \\
2. Private sector & 6688.9 & 9837.6 & 12442.1 & 12720.3 & 12879.6 & 12704.2 \\
B (3+4) Short-term debt & 957.9 & 1050.0 & 2143.3 & 2004.8 & 1830.4 & 647.9 \\
3. Public sector & 56.9 & 33.9 & 17.7 & 1.5 & - & - \\
4. Private sector & 900.9 & 1016.1 & 2125.6 & 2003.3 & 1830.4 & 647.9 \\
\hline
\end{tabular}

Source: Survey Republic of Serbia, 2011, 4

debt. A big problem is the unregulated private debt, which essentially finally becomes the public one. This is corroborated by the fact that the loans concluded before December 2000, in the amount of 884.7 million Euros (of which 405.1 million Euros relate to domestic banks and 479.6 million Euros to domestic companies), are excluded from the external debt of the private sector.

The public debt in the GNP is growing as well: it rose from $30.8 \%$ in 2007 to $45.1 \%$ in 2011 (Survey of Republic of Serbia, 2011).

The distribution of the GDP shows that the Serbian economy spends more than it produces. In 2009, the consolidated government balance showed that the public expenditures exceeded the public revenues by 121.4 billion RSD. In the distribution of the GDP in 2009, consumer spending accounts for $76.5 \%$, and the final consumption of households and the state accounts for 95.9\%. In the same year, that ratio in Croatia was $58.2 \%$ and $77.4 \%$, in Slovenia $53.7 \%$ and $73.3 \%$, and in Slovakia $60.3 \%$ and $79.1 \%$, respectively (Zec \& Radonjić, 2010). The imbalance between consumption and production is covered by the imports of consumer products and energy-generating products, not by the import of equipment and machinery. As the expenditure on equipment and machinery is very small, and without investing it is not possible to increase exports, the imbalance of consumption and production is not sustainable in the long-term.

\section{PROBLEMS IN THE RESTRUCTURING OF SERBIA'S ECONOMY}

The problems in the restructuring of the economy are associated with the problems in the privatization of the companies (through tenders and auctions), the problems related to the lack of the autonomous development of the small and medium companies and the restructuring of the public sector.

The effects of the tender privatization in the commercial sector (the tradable goods sector), whose production is intended for export, are unsatisfactory. In this sector, the tenders were mainly unsuccessful (as in the case of the metal sector), or the buyers were incompetent, without the necessary financial resources and with no clear strategy for the recovery and development of the company.

The sale of the small and medium companies through the auction sale was ineffective because at least $30 \%$ of the contracts were terminated. It turns out that the overriding interest of the customers was not the one of buying a business but the one of buying the buildings and the land of those companies. The outcome of such an entrepreneurship is that the damages and future costs of the state for reconstructing the unsuccessfully privatized companies are larger than the revenues from sales.

The restructuring and privatization of the public companies is a problem that has been lasting for almost two decades. The profitable systems were sold under 
such circumstances when social peace needed to be preserved and the budgetary expenditures covered, as was in the case of the sale of Mobtel and Telecom. Financing the expenditure with the privatization revenues and a loss of future profits (which can be reinvested elsewhere in the world) severely reduce the potential for economic recovery. Many economists point out that the restructuring of the public sector can be found a solution to either through privatization or through bankruptcy and liquidation.

The experience of the Western countries in the privatization of the public sector in the 1980's demonstrated that all public companies operating in competitive industries should be privatized, and that it is better to keep natural monopolies in the state's ownership. It turned out that the availability of information from public companies and their control by the state as well as the possibility of applying a large number of industrial policy instruments provide greater benefits than shifting to the capital market control. In other words, in the case of natural monopolies, the efficiency of regulation rather than ownership is a more significant factor for efficient operations, assuming that the de-politicization of regulatory agencies is performed.

\section{CONCLUSION}

Raising national competitiveness has become the most important task of the government of every country. Despite numerous debates on national competitiveness, there is no comprehensive theory to encompass all the aspects of the competitiveness of a country. In an effort to evaluate the economic and business potential of the world economies, the WEF researchers have developed the concept of the Global Competitiveness Index (GCI), linking the micro- and macroeconomic indicators of competitiveness.

The hypothesis that the macroeconomic performances of the national economies are positively correlated with their global competitiveness index is confirmed in the paper in the case of Serbia, Croatia, Slovenia and Slovakia.
The paper confirmed the hypothesis that the poor macroeconomic performances of Serbia's economy and the bad ranking according to the GCI are caused by the systemic limitations in its economy.

The systemic limitations in the Serbian economy are primarily the result of the transition concept and its realization, the concept of macroeconomic stabilization, the concept of institutional reforms, and the restructuring of the economy. The poorly conceived, poorly institutionally arranged and slow process of privatization has destroyed a significant degree of production resources. The deindustrialization of the economy resulted in a decline in competitiveness and the growth of the trade deficit. The institutional reform was inefficient and failed to implement institutions corresponding to the contemporary development of society, technique and technology. In an economy where there is no productivity growth and no profitable production valorized in the world market, macroeconomic stability cannot be achieved in the long term by restrictive monetary and credit policies, which has a number of limitations. The abovementioned systemic limitations reduce the ability of an economy to produce and compete efficiently in the world market.

The ultimate goal of raising the competitiveness of an economy, i.e. raising the standard of living, cannot be achieved without a new development strategy and the elimination of systemic limitations. This means the correction of the economic policy, the strengthening of the market institutions and the rule of the law institutions, the completion of the privatization process (which includes company liquidation) as well as the restructuring of public companies based on the model of the Western countries.

\section{REFERENCES}

Baldwin, R., \& Wyplosz, C. (2010). The Economics of European Integration. Beograd, Srbija: Data Status.

Candelon, K., Kool, C., \& Raabe, K. (2007). Long run real exchange rate determinants: Evidence from eight new EU member states 1999-2003. Journal of Comparative Economics, 35(1), 87-107. 
Dani, R. (2007). One Economics, Many Recipes: Globalization, Institutions and Economic Growth. Princeton University Press.

Dedu, V., \& Dumitresku, B. (2010). The Balassa-Samuelson effect in Romania. Romanian Journal of Economic Forecasting, 13(4), 44-53.

Đuričin, D. (2006). Može li privreda Srbije da ostvari održiv razvoj do 2012. godine. Ekonomika preduzeća, 54(5-6), 209223.

Global Competitiveness Report 2011-2012. World Economic Forum.

http://www.docsfiles.com/pdf/1/chapter-7-is-there-a-goodmeasure-of-competitiveness-from-is.html

http://www.trademap.org/countrymap/Product_SelCountry_ TS.aspx

Krugman, P. (1994). Competitiveness: a Dengerous Obsession. Foreign Affairs, 73(2), 28-44.

Krugman, P., \& Obstfeld, M. (2003). International Economies Theory and Policy. Harper Collins.

Maksimović, Lj. (2010a). On Serbian Economic Competitiveness in Transitional Conditions. In Z. Paszek (Ed.), PolandSerbia, The Challenges of the Scientific Cooperation (pp. 141155). Krakow, Poland: Krakow Society for Education: AFM Publishing House.

Maksimović, Lj. (2010b). Korupcija i njen uticaj na konkurentnost privrede Srbije. U M. Backović (Ed.), Kako povećati konkurentnost privrede i izvoza Srbije (str. 439-446). Beograd, Srbija: Naučno društvo ekonomista Srbije i Ekonomski fakultet u Beogradu.
Mc Fetrige, D. (1995). Competitiveness: concept and measures. Occasional Paper, 5, April. Industry Canada Press.

Nurbel, A. (2007). The Global Competitiveness of the Nations: A Conceptual Discussion. Journal of Business and Economics Research, 5(10), 63-72.

Porter, M. (1990). The Competitive Adventage of Nations. Mac Milan Business.

Porter, M. (2008). O konkurenciji. Beograd, Srbija: Fakultet za ekonomiju, finansije i administraciju.

Potrer, M., Sachs, J., \& Mc Arthur, J. (2001). Executive Summary: Competitiveness and Stages of Economic Development. The Globall Competitiveness Report. World Economic Forum.

Schuller, B., \& Lidbom, M. (2009). Competitiveness of Nations in the Global Economy. Is Europe Internationally Competitive? Economics \& Management, 14, 934-939.

Smit, A. (2010). The competitive adventage of nations: is Porter's Diamond Framework a new theory that explains the international competitiveness of countries? Southern African Business Review, 14(1), 105-130.

Survey Republic of Serbia. 2011 (4). Jugoslovenski pregled.

Survey Republic of Serbia. 2012 (1). Jugoslovenski pregled.

Tranzition Report (2011). EBRD.

Zec, M., \& Radonjić, O. (2010). Sistemski deficit i tranzicija u Srbiji. U M. Backović (Ed.), Ekonomsko socijalna struktura Srbije (str. 139-165). Beograd, Srbija: Naučno društvo ekonomista Srbije i Ekonomski fakultet u Beogradu.

Received 12 June 2012, after one revision, accepted for publication 9 July 2012

Ljiljana Maksimovic is an Associate Professor at the Faculty of Economics, University of Kragujevac, Serbia. She received her Ph.D. degree from the Faculty of Economics, University of Kragujevac. She teaches the following courses: Price Policies and Theory, Contemporary Economics, Analysis of Competitiveness. The main fields of her scientific interests are transition, privatization, oligopoly, supply concentration, TNC strategies and the competition policy. 


\title{
SISTEMSKA OGRANIČENJA KONKURENTNOSTI PRIVREDE SRBIJE
}

\author{
Ljiljana Maksimović* \\ Ekonomski fakultet Univerziteta u Kragujevcu
}

\begin{abstract}
U radu se analiziraju načini merenja konkurentnosti kao i Globalni indeks konkurentnosti koji, prema metodologiji Svetskog ekonomskog foruma, rangira konkurentnost zemalja u globalnim okvirima. Polazi se od hipoteze da su makroekonomske performanse nacionalnih privreda u pozitivnoj korelaciji sa njihovim globalnim indeksom konkurentnosti, koja se dokazuje na primeru Srbije, Hrvatske, Slovenije i Slovačke. Druga hipoteza je da su loše makroekonomske performanse privrede Srbije i loš rang prema Globalnom indeksu konkurentnosti, rezultat sistemskih ograničenja u privredi Srbije. Analiza u radu ukazuje da su sistemska ograničenja, kao što su koncept tranzicije (privatizacije) i njegova realizacija, koncept makroekonomske stabilizacije, koncept institucionalnih reformi i koncept restrukturiranja privrede, glavni uzročnici nekonkurentnosti privrede Srbije.
\end{abstract}

Ključne reči: konkurentnost, globalni indeks konkurentnosti, sistemska ograničenja

JEL Classification: E02, D02, F43, O11, 012

\section{UVOD}

Predmet analize je konkurentnost privrede Srbije koja se komparira sa konkurentnošću Slovenije, Hrvatske, Slovačke. Cilj rada je da ukaže da su sistemska ograničenja u privredi Srbije bila izraženija $\mathrm{u}$ odnosu na pomenute zemlje $\mathrm{u}$ tranziciji, što se odrazilo i na spoljnotrgovinski bilans i globalni indeks konkurentnosti posmatranih zemalja. U radu se polazi od sledećih hipoteza: prva hipoteza je da su makroekonomske performanse Srbije i posmatranih

\footnotetext{
* Korespondencija: Lj. Maksimović, Ekonomski fakultet Univerziteta u Kragujevcu, Đ. Pucara 3, 34000 Kragujevac, Srbija; e-mail: maksimoviclj@kg.ac.rs
}

zemalja $\mathrm{u}$ pozitivnoj korelaciji sa njihovim globalnim indeksom konkurentnosti; druga hipoteza je da su sistemska ograničenja u privredi Srbije (koncept tranzicije, koncept makroekonomske stabilizacije, koncept institucionalnih reformi i restrukturiranja javnih preduzeća) glavni uzročnici nekonkurentnosti privrede Srbije.

U cilju potvrde postavljenih hipoteza koristi se komparativna analiza makroekonomskih performansi i globalnog indeksa konkurentnosti Srbije i posmatranih zemalja i Pirsonov koeficijent korelacije između globalnog indeksa konkurentnosti i GDP p/c analiziranih zemalja. 


\section{O KONCEPTU NACIONALNE KONKURENTNOSTI}

Ekonomisti nacionalnu konkurentnost shvataju i definišu na različite načine, tako da se koncepti nacionalne, međunarodne i globalne konkurentnosti $\mathrm{u}$ mnogim aspektima preklapaju. Pored brojnih formalnih razlika $u$ definisanju nacionalne, međunarodne i globalne konkurentnosti, većina definicija sadrži brojne zajedničke elemente. Tako se $\mathrm{u}$ svim definicijamakonkurentnostinaglašava sposobnost zemlje da dostigne održive visoke stope ekonomskog rasta GDPp/c i sposobnost da proizvodi dobra i usluge koji zadovoljavaju test svetskog tržišta. U skladu sa raznovrsnošću koncepata konkurentnosti, razvijeni $\mathrm{su}$ i različiti pristupi u merenju konkurentnosti. McFetridge (1995) zaključuje da se generalno mogu izdvojiti dve opcije u merenju konkurentnosti. Prva se bazira na određivanju dohotka per capita ili rastu produktivnosti, a druga na određivanju učinka u međunarodnoj trgovini.

Savremeni koncept konkurentnosti jedne privrede podrazumeva da se kompanije bore za tržišta i resurse $\mathrm{i}$ da koriste poslovne strategije kako bi poboljšale svoje učinke i profitabilnost na nacionalnom i međunarodnom nivou. On povezuje mikroekonomske i makroekonomske faktore konkurentnosti (Nurbel, 2007), odnosno cenovnu konkurentnost (koja je mikroekonomski koncept) sa spoljnotrgovinskim bilansom (koji predstavlja makroekonomski koncept). Mikroekonomski koncept cenovne konkurentnosti bazira se na troškovima i poslovnoj strategiji firme i utiče na spoljnotrgovinski bilans putem izvoznih i uvoznih cena. S druge strane, makroekonomski faktori kao što su devizni kursevi (na koje firma ne može da utiče), deluju na cenovnu konkurentnost firme. Mikroekonomske odluke firme i makroekonomski faktori utiču na cenovnu konkurentnost izvoza i uvoza, a cenovna konkurentnost je snaga koja pokreće trgovinske tokove i utiče na trgovinski bilans.

Cenovna konkurentnost nije jedina odrednica trgovinskog bilansa. On odražava kolektivne akcije pojedinačnih potrošača, firmi i vlade, i predstavlja razliku između domaće agregatne proizvodnje i agregatne potrošnje. Kada zemlja troši više nego što proizvodi, imaće deficit čak i kada su radnici (prema najamninama) i proizvođači (prema cenama proizvoda) konkurentni na svetskom tržištu.

Cene su mera konkurentnosti $\mathrm{u}$ datom trenutku. Konkurentnost $\mathrm{u}$ dugom roku bazira se na kvalitetu resursa koje firme koriste $\mathrm{u}$ proizvodnji dobara $\mathrm{i}$ usluga, kao i na odlukama domaćinstava, firmi i vlade da troše i štede. Pored navedenog, brojni su faktori koji utiču na dugoročnu sposobnost zemlje da proizvodi i da se takmiči na svetskom tržištu: efikasnost sa kojom finansijska tržišta transformišu štednju u investicije, sposobnost i brzina prihvatanja tehnoloških inovacija, sposobnost radnika da steknu veštine koje zahteva tržište rada, kvalitet poslovnih odluka menadžmenta i političkih odluka vlade i drugi faktori (Dani, 2007).

Danas je pažnja fokusirana na značaj konkurentskih prednosti nacija i njihov uticaj na ekonomski rast i životni standard (Porter et al, 2001). Osnovna ideja je da ukoliko zemlja efikasno identifikuje pravi izvor svoje konkurentnosti, onda ce se suočiti sa manje problema tokom ekonomskog razvoja. U tom kontekstu konkurentnost je povezana sa produktivnošću. Rast produktivnosti jeste ključni faktor rasta dohotka per capita; ključni faktor rasta produktivnosti jeste inovativnost; ključni faktor inovativnosti jeste funkcionisanje romba nacionalne prednosti (klastera) kao inovativnog sistema. Prema Porteru (1990) zemlje sa jakim klasterima imaće više stope rasta produktivnosti i nesumnjivu prednost $\mathrm{u}$ odnosu na zemlje sa slabim klasterima. U tom kontekstu važno je razumeti determinante produktivnosti i stopu rasta produktivnosti $\mathrm{u}$ konkretnim delatnostima $\mathrm{i}$ segmentima industrije (Porter, 2008).

Prema Porteru (1990), međunarodnu konkurentnost opredeljuju sledeći fenomeni: 1) makroekonomski fenomeni kao što su devizni kursevi, kamatne stope, budžetski deficit; 2) jeftina i obilna radna snaga; 3) raspoloživost prirodnih resursa; 4) različite menadžerske prakse; 5) niski jedinični troškovi radne snage; 6) pozitivni trgovinski bilans; 7) visoka i stalno rastuća produktivnost.

Koncept nacionalne konkurentnosti kritikovao je Pol Krugman (1994), istakavši da domaći faktori dominantno utiču na nivo GDPp/c i blagostanja, a ne nacionalna konkurentnost potvrđena na svetskom tržištu. On naglašava da se $u$ definisanju nacionalne 
konkurentnosti ističe značaj strukturalnih faktora (produktivnosti, inovacija, veština) a zanemaruje suština konkurentske prednosti, a to su komparativne prednosti. Kada ekonomije trguju, one se ne takmiče na konfrontirajući način (kao što to čine firme), već posluju tako da svaka strana ima određenu korist (plus-sum game). Zemlje se specijalizuju za ona dobra koja proizvode jeftino, odnosno čiji su oportunitetni troškovi niži (Krugman \& Obstfeld, 2003).

Danas je opšteprihvaćen indikator globalne konkurentnosti zemalja Globalni indeks konkurentnosti (GCI), utvrđen prema metodologiji Svetskog ekonomskog foruma (WEF), iako su analitičari ukazali na nedostatke i manjkavosti u njegovom koncipiranju (Smit, 2010). Istraživači WEF-a su pomoću koncepta GCI izvršili sintezu mikroekonomskih i makroekonomskih pokazatelja konkurentnosti, uvažavajući i usaglašavajući preporuke teorije rasta i razvoja, savremene institucionalne ekonomije i primenjene poslovne ekonomije. Na taj način teorijski i praktično su povezali strategijske aspekte poslovne konkurentnosti na nivou pojedinačnog preduzeća sa ukupnim okruženjem na nivou sektora, industrija i cele privrede (Maksimović, 2010a). Analize su pokazale (Schuller \& Lidbom, 2009) da zemlje koje su visoko rangirane prema GCI su visoko rangirane prema dohotku per capita, odnosno prema životnom standardu. Pearson-ov koeficijent korelacije izmedju ranga GCI i GDP per capita je veoma visok i pozitivan.

GCI je kompozitni indeks koji se formira kao ponderisani prosek vrednosti dvanaest stubova konkurentnosti (Institucije, Infrastruktura, Makroekonomska stabilnost, Zdravstvo i primarno obrazovanje, Visoko obrazovanje i obuka, Efikasnost tržišta dobara, Efikasnost tržišta rada, Sofisticiranost finansijskog tržišta, Tehnološka spremnost, Veličina trišta, Sofisticiranost poslovnih procesa i Inovacije). Navedeni stubovi obuhvataju mikroekonomske i makroekonomske faktore koji zajedno sa institucijama određuju konkurentnost nacionalne privrede $u$ globalnim okvirima. Svaki od navedenih stubova predstavlja kompozitni indeks koji se formira kao ponderisani prosek podindikatora. Kompozitni indikatori se dobijaju agregiranjem više pojedinačnih indikatora, koji mere posebne dimenzije posmatranog višedimenzionalnog fenomena. Metodologija za konstrukciju kompozitnih indeksa oslanja se na konzistentan teorijski okvir, na izbor pojedinačnih indikatora, na korišćenje odgovarajućeg tipa multivarijacione analize i određivanje sistema pondera i procedure agregiranja. Vrednosti podindikatora se dobijaju ili iz statističkih izveštaja ili na osnovu standardizovanih anketa, koje svake godine popunjava "top" menadžment reprezentativnog uzorka preduzeća. Vrednost podindikatora za koje ne postoje međunarodno uporedive baze podataka određuju se samo na osnovu ankete $\mathrm{i}$ to rangiranjem od 1 do 7 (uslovi poslovanja, tržišna klima, sloboda štampe, pravna regulativa, politička situacija, sofisticiranost finansijskih tržišta, efikasnost antimonopolske politike).

Za obračun podindikatora konkurentnosti kao što su stopa inflacije, budžetski deficit, nivo poreza, broj telefonskih linija, broj procedura da se započne posao, koriste se međunarodno uporedive baze podataka Ujedinjenih nacija, Svetske banke, MMF, Međunarodne trgovinske organizacije. U okviru GIC učešće podataka iz ankete (primarni podaci ili soft data) je oko $70 \%$, dok je učešće sekundarnih, tvrdih podataka (hard data) oko $30 \%$.

Činjenica da se neke kategorije koje su važne za konkurentan profil jedne zemlje mogu oceniti samo putem ankete, sadrži mogućnost da ocene podindikatora budu precenjene ili potcenjene. Nerealna ocena podindikatora se preko stubova konkurentnosti prenosi i na konačnu vrednost Globalnog indeksa konkurentnosti i na rang zemlje.

\section{KONKURENTSKA POZICIJA SRBIJE, HRVATSKE, SLOVENIJE I SLOVAČKE}

Pozicija Srbije na rang listi zemalja po konkurentnosti WEF vrlo je nepovoljna. U izveštaju WEF za 2011. godinu, Srbija je rangirana kao 95. na listi od 142 zemlje, dok Hrvatska ima rang 76, Slovenija 57 i Slovačka 69.

Srbija se prema GDP po stanovniku (5233 US\$), a prema metodologiji WEF-a, nalazi na srednjem nivou razvijenosti, tj. $u$ drugoj fazi razvoja, $u$ kojoj se kao ključni pokretači konkurentnosti nalaze stubovi 
Tabela 1 Rang i vrednost indeksa za Srbiju, Hrvatsku, Sloveniju i Slovačku u 2011.

\begin{tabular}{|c|c|c|c|c|c|c|}
\hline Zemlja & 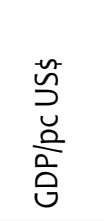 & 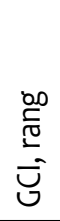 & 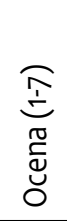 & 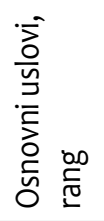 & 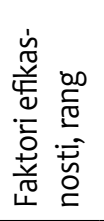 & 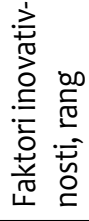 \\
\hline Srbija & 5233 & 95 & 3,9 & 88 & 90 & 118 \\
\hline Hrvatska & 13720 & 76 & 4,1 & 52 & 72 & 82 \\
\hline Slovenija & 23706 & 57 & 4,3 & 39 & 51 & 45 \\
\hline Slovačka & 16104 & 69 & 4,2 & 60 & 44 & 71 \\
\hline
\end{tabular}

Izvor: The Global Competitiveness Report 2011-2012

iz grupe Faktori povećanja efikasnosti. Na realne nedostatke konkurentnosti Srbije ukazuju niske vrednosti podindikatora iz ove grupe, a posledično i izuzetno loš rang (Tabela 2).

Tabela 2 Najslabiji podindikatori iz grupacije faktori povećanja efikasnosti u Srbiji (2011)

\begin{tabular}{lcc}
\hline Faktori povećanja efikasnosti & Vrednost & Rang \\
\hline Stepen obuke zaposlenih & 2,9 & 132 \\
Intenzitet lokalne konkurencije & 3,6 & 136 \\
Stepen tržišne dominacije & 2,5 & 139 \\
Efektivnost antimonopolske politike & 2,8 & 137 \\
Sofisticiranost kupaca & 2,2 & 136 \\
Poverenje u profesionalni & 3,3 & 133 \\
menadžment & 1,8 & 139 \\
Odliv mozgova & 3,7 & 136 \\
Prihvatanje tehnologije od stane & 3,3 & 136 \\
firmi & & \\
Kooperacija radnika i poslodavaca & & \\
\hline
\end{tabular}

Izvor: The Global Competitiveness Report 2011-2012

Dok je intenzitet lokalne konkurencije $\mathrm{u}$ Srbiji ranga 136, u Sloveniji je 51, u Hrvatskoj 115, a u Slovačkoj 37. Prema prihvatanju tehnologije od strane firmi, Srbija je rangirana na 136. mestu, Slovenija ima rang 84,
Hrvatska 80, a Slovačka 58. Srbija po odlivu mozgova zauzima rang 139, Slovenija 58, Hrvatska 128, a Slovačka 111. Rang Srbije prema stepenu tržišne dominacije je 136, Slovenije 63, Hrvatske 119, a Slovačke 50.

U strukturi faktora povećanja efikasnosti dominiraju "meki" indikatori (65\%), čija se vrednost određuje pomoću anketa. Kako su u pitanju subjektivne ocene u procesu međunarodnog poređenja, može doći do potcenjivanja ili precenjivanja podindikatora i do uticaja na objektivnost pozicije koju neka zemlja zauzima.

Tabela 3 Učešće "mekih" i "tvrdih" podindikatora u strukturi GIC (apsolutno i u \%)

\begin{tabular}{lccc}
\hline & \multicolumn{3}{c}{ Broj indikatora i \% učešća } \\
\cline { 2 - 4 } & Ukupno & Tvrdi & Meki \\
\cline { 2 - 4 } $\begin{array}{l}\text { Osnovni zahtevi } \\
\text { Faktori povećanja } \\
\text { efikasnosti }\end{array}$ & 56 & $16(34,8 \%)$ & $30(65,2 \%)$ \\
$\begin{array}{l}\text { Faktori inovativnosti } \\
\text { i sofisticiranosti }\end{array}$ & 18 & $1(54,6 \%)$ & $34(65,4 \%)$ \\
\hline
\end{tabular}

Izvor: The Global Competitiveness Report 2011-2012

Pearson-ov indeks korelacije ranga (GCI) i GDPp/c za posmatrane zemlje je veoma visok i iznosi 0,986 , što govori da postoji veoma jaka pozitivna veza između produktivnosti i ranga konkurentnosti. U izvesnoj meri, na visinu Pearson-ovog koeficijenta utiče mali uzorak od svega četiri zemlje.

Poređenjem "tvrdih" indikatora (deficit državnog budžeta, učešće nacionalne štednje u GDP (\%), godišnja stopa inflacije, učešće javnog duga u GDP (\%)), uočava se lošiji rang Srbije u odnosu na Sloveniju, Hrvatsku i Slovačku (Tabela 4) po svim indikatorima osim prema budžetskom deficitu.

Srbija je $\mathrm{u}$ odnosu na posmatrane zemlje u 2011. godini imala najveću stopu inflacije $(6,2 \%)$, najmanje učešće štednje u BDP $(14,8 \%)$ i najveće učešće javnog duga $u$ $\operatorname{BDP}(44 \%)$. 
Tabela 4 "Tvrdi" indikatori za Srbiju, Hrvatsku, Sloveniju i Slovačku (2011)

\begin{tabular}{lcccccccc}
\hline Zemlje & $\begin{array}{c}\text { Budžetski deficit } \\
\text { (\%GDP) }\end{array}$ & Rang & $\begin{array}{c}\text { Nacionalna štednja } \\
\text { (\%GDP) }\end{array}$ & Rang & $\begin{array}{c}\text { Stopa } \\
\text { inflacije }\end{array}$ & Rang & $\begin{array}{c}\text { Javni dug } \\
\text { (\%GDP) }\end{array}$ & Rang \\
\hline Srbija & $-3,5$ & 66 & 14,8 & 103 & 6,2 & 106 & 44 & 85 \\
Hrvatska & $-5,3$ & 99 & 21,7 & 59 & 1,0 & 1 & 40 & 74 \\
Slovenija & $-5,2$ & 98 & 22,2 & 56 & 1,8 & 1 & 37,2 & 60 \\
Slovačka & $-8,2$ & 130 & 20,2 & 68 & 0,7 & 1 & 42,0 & 81 \\
\hline
\end{tabular}

Izvor: Global Competitiveness Report 2010-2011

Makroekonomski indikatori za posmatrane zemlje, (Tabela 5.1 do 5.6.), koji su prezentirani u Izveštaju Evropske banke za obnovu i razvoj za 2011. godinu, ukazuju da je Srbija sa najvećom stopom inflacije, sa najvećim deficitom tekućeg računa platnog bilansa $(9,6 \%$ u odnosu na BDP), sa niskom stopom privrednog rasta $(1,6 \%)$ i visokim budžetskim deficitom $(4,8 \% \mathrm{u}$ odnosu na BDP).

Tabela 5.1 Stope rasta bruto domaćeg proizvoda (GDP) u \%

\begin{tabular}{lcccc}
\hline Zemlja & 2007. & 2008. & 2009. & $\begin{array}{c}2010 . \\
\text { projekcija }\end{array}$ \\
\hline Srbija & 6,9 & 5,5 & $-3,1$ & 1,6 \\
Hrvatska & 5,5 & 2,4 & $-5,8$ & $-1,5$ \\
Slovenija & 6,9 & 3,7 & $-8,1$ & 1,1 \\
Slovačka & 10,6 & 6,2 & $-4,7$ & 4,0 \\
\hline
\end{tabular}

Izvor: Transition Report 2011

Tabela 5.2 Inflacija u toku godine

\begin{tabular}{lcccc}
\hline Zemlja & 2007. & 2008. & 2009. & $\begin{array}{c}2010 . \\
\text { projekcija }\end{array}$ \\
\hline Srbija & 11,0 & 8,6 & 6,6 & 7,7 \\
Hrvatska & 5,8 & 2,9 & 1,9 & 2,8 \\
Slovenija & 5,6 & 2,1 & 1,8 & 2,1 \\
Slovačka & 3,4 & 4,4 & 0,5 & 1,0 \\
\hline
\end{tabular}

Izvor: Transition Report 2011
Tabela 5.3 Deficit budžeta u \% u odnosu na BDP

\begin{tabular}{lcccc}
\hline Zemlja & 2007. & 2008. & 2009. & 2010. \\
\hline Srbija & $-1,9$ & $-2,6$ & $-4,2$ & $-4,8$ \\
Hrvatska & $-2,5$ & $-1,4$ & $-3,3$ & $-4,7$ \\
Slovenija & 0,0 & $-1,8$ & $-5,8$ & $-5,7$ \\
Slovačka & $-1,8$ & $-2,1$ & $-7,9$ & $-7,5$ \\
\hline
\end{tabular}

Izvor: Transition Report 2011

Tabela 5.4 Tekući račun platnog bilansa u \% u odnosu na BDP

\begin{tabular}{lcccc}
\hline Zemlja & 2007. & 2008. & 2009. & 2010. \\
\hline Srbija & $-15,7$ & $-17,9$ & $-5,6$ & $-9,6$ \\
Hrvatska & $-7,6$ & $-9,2$ & $-5,2$ & $-3,8$ \\
Slovenija & $-4,8$ & $-6,1$ & $-1,0$ & $-1,0$ \\
Slovačka & $-4,7$ & $-6,3$ & $-3,2$ & $-1,5$ \\
\hline
\end{tabular}

Izvor: Transition Report 2011

Tabela 5.5 Neto strane direktne investicije (mil. US\$)

\begin{tabular}{lcccc}
\hline Zemlja & 2007. & 2008. & 2009. & $\begin{array}{c}2010 . \\
\text { projekcija }\end{array}$ \\
\hline Srbija & 2523 & 2717 & 1865 & 1364 \\
Hrvatska & 4736 & 4653 & 1600 & 390 \\
Slovenija & -273 & 514 & -743 & -200 \\
Slovačka & 2881 & 3156 & -481 & 1500 \\
\hline
\end{tabular}

Izvor: Transition Report 2011 
Tabela 5.6 Spoljni dug u \% u odnosu na BDP

\begin{tabular}{lcccc}
\hline Zemlja & 2007. & 2008. & 2009. & $\begin{array}{c}2010 . \\
\text { projekcija }\end{array}$ \\
\hline Srbija & 64,9 & 65,5 & 73,6 & nema pod. \\
Hrvatska & 83,4 & 81,9 & 101,9 & nema pod. \\
Slovenija & 100,6 & 105,2 & 113,4 & nema pod. \\
Slovačka & 52,7 & 53,4 & 74,3 & nema pod. \\
\hline
\end{tabular}

Izvor: Tranzition Report 2011. EBRD.

Postoji saglasnost ekonomista da je kretanje BDP dobar polazni pokazatelj uspešnosti privrednog razvoja zemalja. Izveštaj EBRD-a ukazuje da od navedenih zemalja samo Srbija nije dostigla predtranzicioni nivo $\mathrm{BDP}$, dok su ostale zemlje zabeležile dinamičan rast. Hrvatski BDP u 2010. je malo iznad nivoa BDP iz 1989, BDP Slovenije je 160\%, BDP Slovačke je 145\% a Srbije svega $70 \%$ u odnosu na nivo iz 1989.

Deficit trgovinskog bilansa Srbije govori o niskoj konkurentnosti privrede. U tabelama od broja 6.1. do broja 6.4. dat je pregled trgovinskih bilansa analiziranih zemalja.

Uvoz, izvoz i spoljnotrgovinski deficit Srbije, Hrvatske, Slovenije i Slovačke (2007-2010), tabele 6.1. do 6.4.

Tabela 6.1

\begin{tabular}{lcccc}
\hline Srbija & 2007. & 2008. & 2009. & 2010. \\
\hline Uvoz (a+b) & 21337 & 26227 & 18791 & 20884 \\
a) proizvodi & 18554 & 22875 & 16047 & 16734 \\
b) usluge & 2783 & 3352 & 2744 & 4150 \\
Izvoz (c+d) & 11445 & 14275 & 11279 & 14018 \\
c) proizvodi & 8825 & 10972 & 8345 & 9795 \\
d) usluge & 2620 & 3303 & 2934 & 4223 \\
Saldo (a+b)-(c+d) & -9892 & -11952 & -7512 & -6868 \\
\hline
\end{tabular}

Izvor: http://www.trademap.org/countrymap/Product_ SelCountry_TS.aspx
Tabela 6.2

\begin{tabular}{lcccc}
\hline Hrvatska & 2007. & 2008. & 2009. & 2010. \\
\hline Uvoz $(a+b)$ & 29741 & 35327 & 25073 & 23519 \\
a) proizvodi & 25829 & 30727 & 21205 & 20067 \\
b) usluge & 3912 & 4600 & 3868 & 3452 \\
Izvoz (c+d) & 24877 & 28951 & 22263 & 22831 \\
c) proizvodi & 12360 & 14124 & 10492 & 11811 \\
d) usluge & 12517 & 14827 & 11771 & 11020 \\
Saldo $(a+b)-(c+d)$ & -4864 & -6376 & -2810 & -687 \\
\hline
\end{tabular}

Izvor: http://www.trademap.org/countrymap/Product_ SelCountry_TS.aspx

Tabela 6.3

\begin{tabular}{lcccc}
\hline Slovenija & 2007. & 2008. & 2009. & 2010. \\
\hline Uvoz (a+b) & 33716 & 39183 & 28271 & 30740 \\
a) proizvodi & 29476 & 33985 & 23844 & 26360 \\
b) usluge & 4240 & 5198 & 4427 & 4380 \\
Izvoz (c+d) & 32224 & 36640 & 28269 & 29966 \\
c) proizvodi & 26551 & 29253 & 22294 & 24188 \\
d) usluge & 5673 & 7387 & 5975 & 5778 \\
Saldo (a+b)-(c+d) & -1492 & -2543 & -2 & -774 \\
\hline
\end{tabular}

Izvor: http://www.trademap.org/countrymap/Product SelCountry_TS.aspx

Tabela 6.4

\begin{tabular}{lcccc}
\hline Slovačka & 2007. & 2008. & 2009. & 2010. \\
\hline Uvoz (a+b) & 65698 & 82499 & 64143 & 73562 \\
a) proizvodi & 59208 & 72612 & 55160 & 65916 \\
b) usluge & 6490 & 9887 & 8983 & 7646 \\
Izvoz (c+d) & 65058 & 79332 & 62596 & 71244 \\
c) proizvodi & 58036 & 70189 & 55553 & 64687 \\
d) usluge & 7022 & 9144 & 7043 & 6557 \\
Saldo (a+b)-(c+d) & -640 & -3167 & -1547 & -2318 \\
\hline
\end{tabular}

Izvor: http://www.trademap.org/countrymap/Product_ SelCountry_TS.aspx

Jedan od pokazatelja niske konkurentnosti Srbije jeste i vrlo nizak izvoz, bilo da se posmatra u apsolutnim 
veličinama, bilo $u$ odnosu na broj stanovnika ili kao odnos izvoza i BDP. Na bazi podataka o ostvarenom BDP i broju stanovnika iz izveštaja WEF za 2011. godinu (8 miliona stanovnika u Srbiji, 4,4 mil. u Hrvatskoj, 2,0 mil. u Sloveniji i 5,4 mil. u Slovačkoj) i vrednosti izvoza analiziranih zemalja, zaključuje se da je Srbija ostvarila samo 1752 US\$ izvoza po stanovniku, Hrvatska 5183 US\$, Slovenija 14983 US\$ a Slovačka 13193 US\$. U 2010. godini pokrivenost uvoza izvozom za Srbiju je 67,1\%, za Hrvatsku 97,1\%, za Sloveniju 97,5\% a za Slovačku $96,8 \%$.

\section{PROBLEMI U TRANZICIJI PRIVREDE SRBIJE}

Ekonomski eksperti su predviđali, a dvadesetogodišnji period i potvrdio, da je tranzicija dug i destabilizirajući proces. Radikalna transformacija sistema iz socijalističkog u kapitalistički podrazumevala je sprovođenje sinhronizovanih aktivnosti (makroekonomske stabilizacije, korporativizacije, privatizacije, institucionalne reforme, liberalizacije cena i trgovine i spoljnotrgovinskog režima), koje su neminovno prouzrokovale tranzicionu stagflaciju (pad privredne aktivnosti i rast inflacije). U zemljama koje su bile dosledne u sprovođenju programa tranzicije i koje su je sprovele u kraćem roku, tranziciona kriza je trajala kratko (od 3 do 5 godina) i imala je blaže ekonomske i socijalne posledice. Već posle desetogodišnje tranzicije jedan broj uspešnih tranzicionih privreda je dostigao nivo BDP iz 1989, dok Srbija to nije postigla ni u 2012. Tranzicija je u Srbiji bila spora, nedosledna, dodatno otežavana raspadom zemlje, ratovima $u$ okruženju, sankcijama Ujedinjenih nacija, NATO bombardovanjem i duboko ukorenjenom sistemskom korupcijom (Maksimović, 2010b). Loše koncipiran proces privatizacije realizovao se $u$ neuređenom institucionalnom ambijentu, koga su odlikovali nedorečeni i neusaglašeni zakoni i propisi, nedovoljno razvijene i netransparentne procedure. Privatizacija je neuspešna ako rezultate privatizacije posmatramo $u$ svetlu proklamovanih ciljeva, a to su: veća proizvodna i ekonomska efikasnost preduzeća; obezbeđenje zdravog finansiranja preduzeća; uvođenje efikasnog menadžmenta; obezbeđenje priliva stranog kapitala; otvaranje prostora preduzetništvu; oslobađanje preduzeća od uticaja države i politike; porast konkurencije; razbijanje monopola i ograničavanje njihovog uticaja; likvidacija nerentabilnih preduzeća.

Efekti rasta efikasnosti privređivanja privatizovanih preduzeća ne utiču značajnije na rast nivoa privredne aktivnosti. Očekivanja o obimu stranih direktnih investicija (SDI) u realni sektor nisu se ostvarila, jer je strani kapital prevashodno bio usmeren ka bankama, osiguranju, monopolskim preduzećima i akciznoj robi, a manje ka sektoru razmenljivih dobara. Neto iznos SDI u periodu 2001-2011. bio je oko 15 milijardi evra, od čega je $40 \%$ investirano u procesu privatizacije privrede i sektora finansija. Taj iznos nije bio dovoljan za oporavak privrede, posebno industrije, jer je oko $35 \%$ ukupnog priliva SDI bilo usmereno u sektor nerazmenljivih dobara i usluga, a samo oko $15 \%$ bile su green field investicije (Survey Republic of Serbia, 2012). Efikasnost SDI u procesu privatizacije je niska: od ukupno 222 preduzeća koja su u periodu 2002-2010. ponuđena na prodaju putem tendera, 108 je prodato a 24 ugovora su raskinuta. U slučaju aukcijske privatizacije, od ponuđenih 2453 preduzeća, prodato je 1645 a skoro jedna trećina ugovora je raskinuta (501), (Zec \& Radonjić, 2010). Privatizacija putem tendera počela je od najboljih preduzeća: u pitanju su cementare, fabrike duvana, pivare, farmaceutske kompanije, naftne kompanije. Takvom ponudom država je nastojala da popravi investicioni imidž i da privuče transnacionalne korporacije. Putem aukcije su prodata manja preduzeća koja su prevashodno kupljena radi imovine i likvidacije. Država je u aukcijskim privatizacijama pod pritiskom preduzetničkih lobija po niskoj početnoj ceni prodavala preduzeća, jer ih je vrednovala kao biznis. Kupci su koristili jeftine bankarske kredite za kupovinu preduzeća sa namerom da ih likvidiraju i da dođu do imovine. Preduzetništvo u uslovima tranzicije se ispoljavalo na sledeći način: neki su postali preduzetnici tako što su imali mogućnost da putem poslovnih transakcija u uslovima hiper inflacije izvrše transfer bogatstva u svoje ruke; drugi su koristili kredite za preuzimanje preduzeća, pogrešno procenjujući da mogu nastaviti sa uzimanjem kredita za kapitalne invasticije i obrtna sredstva. Pokazalo se da novi preduzetnici opstanak preuzetih preduzeća baziraju na neekonomskim i političkim polugama. 


\section{MAKROEKONOMSKA STABILIZACIJA}

Kvalitet makroekonomske stabilizacije meri se stabilnošću cena, ravnotežnim i stabilnim kursom nacionalne valute, eliminisanjem budžetskog deficita države. Makroekonomske performanse privrede govore da u zemlji postoji stalan inflatorni pritisak, jer je agregatna tražnja veća od agregatne ponude. Fiskalna ekspanzija, zbog odlaganja prestrukturiranja javnih preduzeća, i monetarna ekspanzija, prevashodno izazvana prilivom kreditnog kapitala, dodatno jačaju inflatorni pritisak. Inflacija u Srbiji je praćena apresijacijom domaće valute, što je uticalo na pad konkurentnosti privrede i usporavanje rasta. Pojedini ekonomisti ističu da su dometi restriktivne monetarne politike u suzbijanju inflacije vrlo ograničeni i da kurs apresira čak i u režimu slobodnog fluktuiranja i to objašnjavaju Balassa-Samuelson efektom (Candelon, 2000; Đuričin, 2006; Dedu, 2010). Balassa i Samuelson su pošli od pretpostavke da se privreda može podeliti na dva sektora: sektor razmenljivih dobara (roba), koja su predmet međunarodne trgovine i sektor nerazmenljivih dobara (usluge), kojima se ne trguje na međunarodnom tržištu. Produktivnost brže raste u sektoru razmenljivih dobara, što rezultira rastom plata zaposlenih $\mathrm{u}$ tom sektoru. Zbog efekta ugledanja dolazi do rasta plata u sektoru nerazmenljivih dobara, koje se mogu pokriti samo povećanjem cena (Baldwin \& Wyplosz, 2010). Primena Balassa-Samuelson-ovog efekta u slučaju Srbije nameće sledeći zaključak: relativno viša stopa domaće inflacije od inostrane ne utiče $\mathrm{u}$ potpunosti na nominalni devizni kurs, pošto su za njegovo formiranje važnije cene razmenljivih proizvoda (koje rastu sporije) od cena nerazmenljivih proizvoda (koje rastu brže). Kako paritet kupovne moći ne funkcioniše $u$ tranzicionim privredama, njihove valute depresiraju za manji iznos u odnosu na stopu inflacije. Posledica je apresijacija, odnosno sporiji rast kursa domaće valute od rasta inflacije. Realna apresijacija dinara, zahvaljujući kojoj su cene proizvoda i usluga u Srbiji, izražene u evrima, znatno porasle, ima za posledicu velike profite $u$ trgovini. Time se podstiče ulaganje u trgovinu, a destimulišu ulaganja $u$ proizvodnju.

Srbija je veoma zadužena zemlja, o čemu govori odnos između BDP i spoljnog duga. Veliki problem predstavlja neregulisan privatni dug, koji u suštini na kraju postaje državni. U prilog tome govori podatak da su iz spoljnog duga privatnog sektora isključeni krediti zaključeni pre decembra 2000. u iznosu 884,7 mil. evra (od čega se 405,1 mil. evra odnosi na domaće banke, a 479,6 mil. evra na domaća preduzeća).

Raste i učešće javnog duga u DBP, tako da je od 30,8\% u 2007. narastao na 45,1\% u 2011. (Survey Republic of Serbia, 2011).

Raspodela BDP govori da srpska privreda troši više nego što proizvodi. U 2009. konsolidovani bilans države pokazao je da su javni rashodi veći od javnih prihoda za 121,4 mlrd. dinara. U raspodeli BDP u 2009. lična potrošnja učestvuje sa $76,5 \%$, a finalna potrošnja domaćinstava i države sa $95,9 \%$. U istoj godini, taj odnos u Hrvatskoj je 58,2\% i 77,4\%, u Sloveniji 53,7\% i 73,3\% i Slovačkoj 60,3\% i 79,1\% (Zec \& Radonjić, 2010).

Tabela 7 Spoljni dug Srbije prema dužnicima (u mil. EUR)

\begin{tabular}{lrrrrrr}
\hline & 2006. & 2007. & 2008. & 2009. & 2010. & 2011. \\
\cline { 2 - 7 } Stanje spoljnog duga (A+B) & 14182,0 & 17138,7 & 21088,4 & 22487,3 & 23786,4 & 24125,4 \\
A (1+2) Dugoročni dug & 13224,1 & 16088,7 & 18954,1 & 20482,5 & 21956,0 & 23477,5 \\
1. Javni sektor & 6535,3 & 6251,1 & 6503,0 & 7762,3 & 9076,4 & 10773,3 \\
2. Privatni sektor & 6688,9 & 9837,6 & 12442,1 & 12720,3 & 12879,6 & 12704,2 \\
B (3+4) Kratkoročni dug & 957,9 & 1050,0 & 2143,3 & 2004,8 & 1830,4 & 647,9 \\
3. Javni sektor & 56,9 & 33,9 & 17,7 & 1,5 & - & - \\
4. Privatni sektor & 900,9 & 1016,1 & 2125,6 & 2003,3 & 1830,4 & 647,9 \\
\hline
\end{tabular}


Debalans između potrošnje i proizvodnje se pokriva uvozom proizvoda široke potrošnje i energenata, a ne uvozom opreme i mašina. Kako su izdaci za opremu i mašine veoma mali, i kako bez investicija nije moguće povećati izvoz, ovaj nesklad potrošnje i proizvodnje nije dugoročno održiv.

\section{PROBLEMI U RESTRUKTURIRANJU PRIVREDE SRBIJE}

Problemi $\mathrm{u}$ restrukturiranju privrede povezani su sa problemima $u$ privatizaciji preduzeća (putem tendera i aukcija), sa problemima nedovoljnog autonomnog razvoja malih i srednjih preduzeća kao i sa restrukturiranjem javnog sektora.

Učinci tenderske privatizacije $\mathrm{u}$ komercijalnom sektoru (sektoru razmenljivih dobara), čija je proizvodnja namenjena izvozu, nezadovoljavajući su. U ovom sektoru tenderi su uglavnom bili neuspešni (kao u slučaju metalskog sektora), ili su kupci bili nekompetentni, bez potrebnih finansijskih sredstava i bez jasne strategije oporavka i razvoja preduzeća.

Prodaja malih i srednjih preduzeća putem aukcijske prodaje je bila neefikasna, jer je najmanje 30\% ugovora raskinuto. Ispostavilo se da je prevashodni interes kupaca bio kupovina zgrada i zemljišta, a ne biznisa. Ishod takvog preduzetništva je da su štete i budući troškovi države za restrukturiranje neuspešno privatizovanih preduzeća veći od ostvarenih prihoda od prodaje.

Restrukturiranje i privatizacija javnih preduzeća je problem koji traje skoro dve decenije. Profitabilni sistemi se prodaju $u$ okolnostima kada treba sačuvati socijalni mir i pokriti budžetske rashode, kao u slučaju prodaje Mobtela i Telekoma. Finansiranje potrošnje prihodima od privatizacije i gubitak budućih profita (koji mogu da se reinvestiraju bilo gde u svetu), ozbiljno umanjuju potencijale za privredni oporavak. Brojni ekonomisti naglašavaju da se restrukturiranje javnog sektora može rešiti ili privatizacijom ili putem stečaja i likvidacije.

Iskustvo zapadnih zemalja u privatizaciji javnog sektora $u$ osamdesetim godinama dvadesetog veka pokazalo je da treba privatizovati sva javna preduzeća koja posluju u konkurentnim granama, a da je prirodne monopole bolje zadržati u državnoj svojini. Pokazalo se da dostupnost informacija iz javnih preduzeća i njihova kontrola od strane države, kao i mogućnost primene velikog broja instrumenata industrijske politike, pružaju veće prednosti od prelaska na kontrolu od strane tržišta kapitala. Drugim rečima, u slučaju prirodnih monopola, značajniji faktor za efikasno poslovanje jeste efikasnost regulative nego vlasništvo, pod pretpostavkom da se izvrši depolitizacija regulatornih agencija.

\section{ZAKLJUČAK}

Podizanje nacionalne konkurentnosti je postalo najvažniji zadatak vlade svake zemlje. Uprkos brojnim raspravama na temu nacionalne konkurentnosti, ne postoji sveobuhvatna teorija koja bi obuhvatila sve aspekte konkurentnosti jedne zemlje. Istraživači angažovani $u$ WEF-u, u nastojanju da ocene ekonomske i poslovne potencijale privreda $u$ svetu, razvili su koncept Globalnog indeksa konkurentnosti (GCI), povezujući mikroekonomske i makroekonomske pokazatelje konkurentnosti.

Hipoteza, da su makroekonomske performanse nacionalnih privreda $u$ pozitivnoj korelaciji sa njihovim globalnim indeksom konkurentnosti, $u$ radu je potvrđena na primeru Srbije, Hrvatske, Slovenije i Slovačke.

U radu je potvrđena hipoteza da su loše makroekonomske performanse privrede Srbije i loš rang prema GCI uzrokovani sistemskim ograničenjima u privredi.

Sistemska ograničenja $\mathrm{u}$ privredi Republike Srbije rezultat su, pre svega, koncepta tranzicije i njegove realizacije, koncepta makroekonomske stabilizacije, koncepta institucionalnih reformi i restrukturiranja privrede. Loše koncipiran, slabo institucionalno uređen i usporen proces privatizacije uništio je $u$ značajnoj meri proizvodne resurse. Deindustrijalizacija privrede uticala je na pad konkurentnosti i rast trgovinskog deficita. Institucionalna reforma je bila neefikasna i nije uspela da implementira institucije koje odgovaraju 
savremenom razvoju društva, tehnike i tehnologije. U privredi, u kojoj nema rasta produktivnosti, profitabilne $\mathrm{i}$ na svetskom tržištu valorizovane proizvodnje, makroekonomska stabilnost ne može se postići na dugi rok restriktivno monetarno kreditnom politikom, koja ima brojna ograničenja. Navedena sistemska ograničenja umanjuju sposobnost privrede da efikasno proizvodi i konkuriše na svetskom tržištu.

Krajnji cilj podizanja konkurentnosti privrede, a to je podizanje životnog standarda stanovništva, ne može se ostvariti bez nove strategije razvoja i eliminisanja sistemskih ograničenja. To podrazumeva korekciju ekonomske politike, jačanje tržišnih institucija i institucija vladavine prava, završetak procesa privatizacije (koji znači i likvidaciju preduzeća), kao i restrukturiranje javnih preduzeća po modelu zapadnih zemalja.

\section{REFERENCE}

Baldwin, R., \& Wyplosz, C. (2010). The Economics of European Integration. Beograd, Srbija: Data Status.

Candelon, K., Kool, C., \& Raabe, K. (2007). Long run real exchange rate determinants: Evidence from eight new EU member states 1999-2003. Journal of Comparative Economics, $35(1), 87-107$.

Dani, R. (2007). One Economics, Many Recipes: Globalization, Institutions and Economic Growth. Princeton University Press.

Dedu, V., \& Dumitresku, B. (2010). The Balassa-Samuelson effect in Romania. Romanian Journal of Economic Forecasting, 13(4), 44-53.

Đuričin, D. (2006). Može li privreda Srbije da ostvari održiv razvoj do 2012. godine. Ekonomika preduzeća, 54(5-6), 209223.

Global Competitiveness Report 2011-2012. World Economic Forum.

http://www.docsfiles.com/pdf/1/chapter-7-is-there-a-goodmeasure-of-competitiveness-from-is.html

http://www.trademap.org/countrymap/Product_SelCountry_ TS.aspx
Krugman, P. (1994). Competitiveness: a Dengerous Obsession. Foreign Affairs, 73(2), 28-44.

Krugman, P., \& Obstfeld, M. (2003). International Economies Theory and Policy. Harper Collins.

Maksimović, Lj. (2010a). On Serbian Economic Competitiveness in Transitional Conditions. In Z. Paszek (Ed.), PolandSerbia, The Challenges of the Scientific Cooperation (pp. 141155). Krakow, Poland: Krakow Society for Education: AFM Publishing House.

Maksimović, Lj. (2010b). Korupcija i njen uticaj na konkurentnost privrede Srbije. U M. Backović (Ed.), Kako povećati konkurentnost privrede i izvoza Srbije (str. 439-446). Beograd, Srbija: Naučno društvo ekonomista Srbije i Ekonomski fakultet u Beogradu.

Mc Fetrige, D. (1995). Competitiveness: concept and measures. Occasional Paper, 5, April. Industry Canada Press.

Nurbel, A. (2007). The Global Competitiveness of the Nations: A Conceptual Discussion. Journal of Business and Economics Research, 5(10), 63-72.

Porter, M. (1990). The Competitive Adventage of Nations. Mac Milan Business.

Porter, M. (2008). O konkurenciji. Beograd, Srbija: Fakultet za ekonomiju, finansije i administraciju.

Potrer, M., Sachs, J., \& Mc Arthur, J. (2001). Executive Summary: Competitiveness and Stages of Economic Development. The Globall Competitiveness Report. World Economic Forum.

Schuller, B., \& Lidbom, M. (2009). Competitiveness of Nations in the Global Economy. Is Europe Internationally Competitive? Economics \& Management, 14, 934-939.

Smit, A. (2010). The competitive adventage of nations: is Porter's Diamond Framework a new theory that explains the international competitiveness of countries? Southern African Business Review, 14(1), 105-130.

Survey Republic of Serbia. 2011 (4). Jugoslovenski pregled.

Survey Republic of Serbia. 2012 (1). Jugoslovenski pregled.

Tranzition Report (2011). EBRD.

Zec, M., \& Radonjić, O. (2010). Sistemski deficit i tranzicija u Srbiji. U M. Backović(Ed.), Ekonomsko socijalna struktura Srbije (str. 139-165). Beograd, Srbija: Naučno društvo ekonomista Srbije i Ekonomski fakultet u Beogradu. 
Primljeno 12. juna 2012, nakon revizije, prihvaćeno za publikovanje 9. jula 2012.

Ljiljana Maksimović je vanredni profesor na Ekonomskom fakultetu Univerziteta u Kragujevcu, gde je i doktorirala. Izvodi nastavu na predmetima: Teorija i politika cena, Savremena ekonomija i Analiza konkurentnosti. Osnovne oblasti njenog naučnog interesovanja su tranzicija, privatizacija, oligopolizacija, koncentracija ponude, strategije TNK i politike konkurencije. 